\title{
Immortal Drugs: Short Stories from the Early Days of Modern Drug Therapy
}

\author{
Dimitrios Tsilingiris*, Stavros Liatis and Nikolaos Katsilambros \\ First Department of Propaedeutic Internal Medicine, Greece
}

*Corresponding author: Dimitrios Tsilingiris, Medical School, First Department of Propaedeutic Internal Medicine, Laiko General Hospital, 17 Agiou Thoma Street, Athens, Greece

\begin{tabular}{l} 
ARTICLE INFO \\
\hline Received: 幽 January 24, 2019 \\
Published: 幽 February 06, 2019 \\
\hline Citation: Dimitrios T, Stavros L, Niko- \\
laos K. Immortal Drugs: Short Stories \\
from the Early Days of Modern Drug \\
Therapy. Biomed J Sci \& Tech Res \\
14(1)-2019. BJSTR. MS.ID.002501.
\end{tabular}

ABSTRACT

Current clinical medical practice traverses through the era of targeted and individualized therapies. The constant development and expansion of novel drug classes is typically a result of series of years of strenuous and focus research and testing. This fact comes into contrast with the early days of pharmacology, when pharmaceutical agents often evolved from folklore-based remedies, at times discovered as a result of an individual physician or researcher's keen eye, or even emerged through sheer chance. This has endowed contemporary medicine, apart from a series of valuable drugs that have withstood the test of time, with a collection of colorful stories from the dawn of modern therapeutics.

\section{Brief tales from the heart of cardiovascular pharmacology}

Modern evidence-based cardiology still utilizes historical gem drugs in routine everyday practice. The analgesic and antiinflammatory attributes of the salicylate-rich willow bark extracts are mentioned in the 16th century Ebers papyrus [1]. It had been in remedial use already for millennia, from as early as the time of Assyrians, ancient Egyptians and Greeks, when aspirin emerged. In 1897, chemist Felix Hoffman added an acetyl group to salicylic acid which was first synthesized from salicin by Rafaelle Piria earlier in the 19th century [2]. Its use today remains as widespread as ever in the secondary prevention of cardiovascular disease. The antianginal properties of nitroglycerin, which was earlier popularized by Alfred Nobel as a compound of dynamite, were brought to light by British physician William Murrel in 1879 [3]. Exposure to the substance, which was marketed for pharmaceutical purposes as Trinitrin to prevent crowd intimidation, has been speculated to be the aggravating cause of Nobel's late life health problems which included migraine headaches and angina pectoris. To treat the latter, Nobel was ironically prescribed nitroglycerin by his physicians [4].

Digoxin, the oldest surviving inotrope, is extracted from the leaves of Digitalis purpurea and has been in use since medieval times for a variety of indications, including dropsy [5]. Its artistic depiction in Vincent van Gogh's painting "Portrait of Dr. Gatchet" has ignited the hypothesis that the dominance of yellow in his late work as well as the halo surrounding luminous objects in certain of his paintings, are a result of chronic digitalis intoxication which he presumably received for the treatment of "temporal epilepsy" [6]. In the 1920s, the investigation of veterinarians Frank Shofield and Lee Roderick into the causes of a mysterious epidemic outbreak of uncontrollable bleeding among cattle throughout northern USA and Canada, led to the later isolation of dicoumarol which is produced in moldy hay. A stronger related compound was named warfarin and was solely used as a rodenticide until 1951, when a navy recruit survived a warfarin suicide attempt after being administered vitamin $\mathrm{K}[7,8]$. Since then, and despite the arrival of novel oral anticoagulants, coumadin agent have retained an everlastingly prominent position in anticoagulation therapy [9].

\section{The Antiviral First Line Antidiabetic}

The first reports of the synthesis and pharmacology of metformin appeared in medical literature in the 1920s [10]. Previously known were the glucose-lowering effects of guanidine, a compound found in substantial quantities in the extract of Galega officinalis. Although a less toxic guanidine alkaloid, namely galegine, was then used in limited scale for its antihyperglycemic properties, 
the concomitant success regarding the extraction, isolation and purification of insulin nullified its usage during the next decades. That was until 1949, when Filipino physician Eusebio Garcia who was experimenting on the application of metformin for the treatment of influenza observed its glucose normalizing abilities. His observations prompted French diabetologist Jean Sterne to test the compound in humans for the treatment of diabetes [11]. The results of Sterne's research may have been published in the distant 1957 still, metformin continues to hold its place in the first line of type 2 diabetes treatment up until the present.

\section{The Dawn of Antimicrobial Therapy: A Nobel-Winning Race in the Shadow of WW2}

The history of the early days of antimicrobial therapy is largely shaped by the reports about the emergence of two major antibiotic classes, which may be viewed another symbolic rivalry between the clashing powers of the second world war. Well known is the infamous story of biologist Alexander Fleming returning to London's St Mary's Hospital after vacation to find a mould-infested petri dish in which bacterial growth had been suspended. After identifying the mould as Penicillium, the miraculous substance was named Penicillin $[12,13]$. Still, it would take another 10 years for large scale extraction and purification of penicillin to be made possible by Howard Florey, Ernst Chain and Norman Heatley. Systematic human studies were conducted throughout the second world war and eventually, a Nobel prize was awarded to Fleming, Chain and Florey in 1945 [14,15]. Concurrently in Germany, another antibiotic class was being developed: in 1932, bacteriologist Gerhard Domagk discovered the in vivo antimicrobial properties of sulfamidochrysoidine against S. pyogenes in rodents after years of experimenting with Azo dye-related compounds [16].

The substance was marketed under the name Prontosil, was the first commercially available antimicrobial used for a variety of infectious diseases and remained in use up until the 1960s. Domagk was awarded the Nobel prize in 1939 but was arrested by the state of the third Reich and subsequently forced to sign a letter of forfeiture, although he eventually received the prize after the end of the second world war [17]. At the time, Prontosil in Germany was considered a "miracle drug", capable to treat any infection if optimally administered. Subsequently, it appears surprising that it wasn't administered to third Reich's general Reinhard Heydrich (popularly known as "Himmler's brain") after his assassination attempt in 1942 in Prague, who later succumbed to septic complications of his wounds [18]. Even though Prontosil was an effective antibacterial, it was no match for the safety and effectiveness profile of penicillin, still its existence may have hampered any serious attempt towards penicillin development in third Reich Germany. The allies exhibited meticulous caution in retaining all information on penicillin production outside the reach of Axis intelligence and gradually, this started to reflect on battlefield losses between the two sides. Still, penicillin obtained from an unidentified source may have saved Adolf Hitler's life after his assassination attempt in July 1944 [19].

\section{The Fortunate Blunder of Paracetamol Discovery}

In Strasburg of 1884, two young assistants of renowned physician Adolf Kussmaul namely Arnold Kahn and Paul Hepp, prescribed a patient suffering from intestinal parasitosis naphthalene. Treatment proved unsuccessful in eradicating the worms but surprisingly, the patient's fever subsided. Susequent research revealed that the pharmacy had accidentally dispensed acetanilide to the patient, which shared a similar appearance to naphthalene [20]. Acetanilide was marketed under the commercial name "Antifebrin" but it was soon replaced by the safer and longeracting phenacetin [20], which was used for several decades during which the association of its use with the occurrence of cases of nephropathy was established. An active metabolite of phenacetine then gained newfound interest: paracetamol was first synthesized in 1877 by Harmon Morse and tested in clinical practice 20 years later by physician Joseph von Mering but abandoned due to cases of methemoglobinemia falsely attributed to its use [21]. Commercially available since the 1950s, paracetamol gradually became the most frequently used analgesic and one of the most widely marketed drugs globally [22].

\section{The Mythological Antigout Agent}

Colchicine is extracted from the flowers and bulbs of the plant Colchium autumnale, popularly known as meadow saffron. It is named after the ancient kingdom of Colchis (modern Egrisi of Georgia) but there is controversy as regards the further origin of its connection to the region: this was either a plain result of the abundance of the plant in the area or a reference to the myth of Medea, the enchantress daughter of Colchis's king Aeetes, who supposedly used the plant to poison her offspring $[23,24]$. Certain of its medicinal effects were known since the antiquity: its usage against rheumatism and swelling is mentioned in Ebers Papyrus (circa 16th century B.C.) while it was administered in ancient Greece for its laxative properties. The first recorded use of Colchium for the treatment of gout was by Byzantine physician Alexander of Tralles [25]. Around fifteen centuries after, colchicine remains a valuable agent in the treatment of gouty attacks and other inflammatory conditions.

\section{Witchcraft, Divine Punishment or Just Fungi}

Ergot alkaloids such as bromocryptin and ergometrin are tryptophan derivatives that are naturally produced by the infestation of rye, wheat or barley by the fungus Claviceps purpurea, commonly known as Ergot. Due to their chemical origin from tryptophan, they share structural similarities to endogenous and exogenous psychoactive substances such as dimethyltryptamine and lysergic acid diethylamide. Deliberate use of ergot alkaloids as entheogens has been speculated in the Eleusinian mysteries in ancient Greece [26]. Ergot toxicity, historically as a result of yeastinfested rye consumption, produces a clinical picture that includes 
neurological and psychiatric manifestations as well as limb gangrene, collectively called ergotism or ergotoxicosis. Outbreaks of ergot poisoning peaked in medieval Europe and were often viewed as divine punishment. The condition was referred to as St. Anthony's fire, due to the burning limb paresthesias associated with the condition, along with the hospitals of the monastic order of Saint Anthony that were dedicated to ergotism treatment [27]. Ergotism has been speculated to be the underlying disorder of the people accused of witchcraft, condemned during the Salem witch trials in the 17th century [28] as well as a potential cause of the peculiar phenomenon called "dance plague", outbreaks of which stormed late medieval Europe [29]. It was also during this period, that empirical medical use ergot alkaloids began, to reduce postpartum hemorrhage by midwives in Europe, an indication for which they are used up until our days [27].

\section{References}

1. Jack DB (1997) One hundred years of aspirin. Lancet 350(9075): 437439.

2. Mackowiak PA (2000) Brief history of antipyretic therapy. Clinical infectious diseases 31(5): S154-S156.

3. Murrel W (1879) Nitro-Glycerine as a Remedy for Angina Pectoris. The Lancet 113(2890): 80-81.

4. Kantha SS (1997) Could nitroglycerine poisoning be the cause of Alfred Nobel's anginal pains and premature death? Medical hypotheses 49(4): 303-306.

5. Patel S (2016) Plant-derived cardiac glycosides: Role in heart ailments and cancer management. Biomedicine \& pharmacotherapy 84: 10361041

6. Lee TC (1981) Van Gogh's vision. Digitalis intoxication? Jama 245(7): 727-729.

7. Lim GB (2017) Milestone 2: Warfarin: from rat poison to clinical use. Nature reviews Cardiology.

8. Wardrop D, Keeling D (2008) The story of the discovery of heparin and warfarin, British journal of haematology 141(6): 757-763.

9. Wadhera RK, Russell CE, Piazza G (2014) Cardiology patient page. Warfarin versus novel oral anticoagulants: how to choose? Circulation 130(22): e191-193.

10. Sonal GTM, Sekhar, Suhaj A (2014) The story of metformin continues. Journal of Pharmacy Practice and Researcher 44(4): 289-290.

11. Patade G, Marita A (2014) Metformin: A Journey from countryside to the bedside. Journal of Obesity and Metabolic Research 1(2): 127-130.

ISSN: 2574-1241

DOI: 10.26717.BJSTR.2019.14.002501

Muhammad Torequl Islam.Biomed J Sci \& Tech Res

This work is licensed under Creative Commons Attribution 4.0 License

Submission Link: https://biomedres.us/submit-manuscript.php
12. Alharbi SA, Wainwright M, Alahmadi TA, Salleeh HB, Faden AA (2014) What if Fleming had not discovered penicillin? Saudi journal of biological sciences 21(4): 289-293.

13. Zaffiri L, Gardner J, Toledo Pereyra LH (2012) History of antibiotics. From salvarsan to cephalosporins, Journal of investigative surgery : journal of the Academy of Surgical Research 25(2): 67-77.

14. Swann JP (1983) The search for synthetic penicillin during World War II. British journal for the history of science 16(53 Pt 2): 154-190.

15. Gaynes R (2017) The Discovery of Penicillin-New Insights After More Than 75 Years of Clinical Use. Emerging Infectious Diseases 23(5): 849853.

16. Otten H (1986) Domagk and the development of the sulphonamides. Journal of antimicrobial chemotherapy 17(6): 689-696.

17. Chorba T (2018) Peace, Liberty, Mycobacteria, and Tuberculosis Mortality. Emerging Infectious Diseases 24(3): 611-612.

18. Weisz GM, Albury WR (2014) The attempt on the life of Reinhard Heydrich, architect of the "final solution": a review of his treatment and autopsy. The Israel Medical Association journal : IMAJ 16(4): 212-216.

19. Wainwright M, Hitler's penicillin (2004) Perspectives in biology and medicine 47(2): 189-198.

20. Brune K, Renner B, Tiegs G (2015) Acetaminophen/paracetamol: A history of errors, failures and false decisions. European journal of pain 19(7): 953-965

21. Bertolini A, Ferrari A, Ottani A, Guerzoni S, Tacchi R, et al. (2006) Paracetamol: new vistas of an old drug. CNS drug reviews 12(3-4): 250275 .

22. Jozwiak Bebenista M, Nowak JZ (2014) Paracetamol: mechanism of action, applications and safety concern. Acta poloniae pharmaceutica 71(1): 11-23

23. Graham W, Roberts JB (1953) Intravenous colchicine in the management of gouty arthritis. Annals of the rheumatic diseases 12(1): 16-19.

24. Bhattacharjee S (2009) A brief history of gout, International journal of rheumatic diseases 12(1): 61-63.

25. Tsoucalas G, Papaioannou T, Panayiotakopoulos G, Saridaki Z, Vrachatis DA, et al. (2018) Colchicum Genus in the Writings of Ancient Greek and Byzantine Physicians. Current pharmaceutical design 24(6): 648-653.

26. Vetulani J (2001) Drug addiction. Part I. Psychoactive substances in the past and presence, Polish. Journal of pharmacology 53(3): 201-214.

27. Haarmann T, Rolke Y, Giesbert S, Tudzynski P (2009) Ergot: from witchcraft to biotechnology. Molecular plant pathology 10(4): 563-577.

28. Spanos NP (1983) Ergotism and the Salem witch panic: a critical analysis and an alternative conceptualization. Journal of the history of the behavioral sciences 19(4): 358-369.

29. Lanska DJ (2018) The Dancing Manias: Psychogenic Illness as a Social Phenomenon, Frontiers of neurology and neuroscience 42: 132-141.

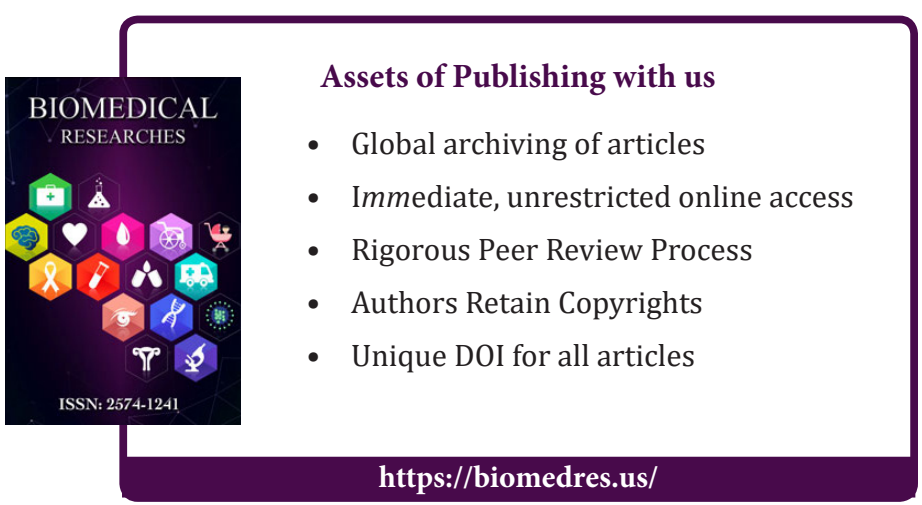

